Jurnal Indonesia Sosial Teknologi: p-ISSN: 2723 - 6609

e-ISSN : 2745-5254

Vol. 1, No. 5 Desember 2020

\title{
PENGUKURAN PEMAHAMAN DAN KESIAPSIAGAAN TERHADAP POTENSI BENCANA GEOLOGI AREA INDRAMAYU DI SMK MIGAS BALONGAN
}

\section{Arief Rahman}

Akamigas Balongan Indramayu

Email: arief11rahman@gmail.com

\section{Abstract}

The geological disaster in Palu-Donggala (Central Sulawesi), September 2018, caused many casualties. In mid-2018, there was a burst of natural gas which caused a burst of fire and hot water in the south of Indramayu, it is estimated that there is an active fault / fault that cuts the rock of the oil and gas reservoir to the earth's surface. Anticipating geological disasters is not only the task of related government agencies, but all related parties, such as Akamigas Balongan. The purpose of this research is to measure how much you know and be alert in dealing with geological disasters, as well as to measure the knowledge of government agencies / agencies that handle geological disasters. SMK Migas Balongan, is the SMK most related to geology, especially oil and gas. The research was conducted in December 2018, with a questionnaire method with a weighted question for potential types of natural disasters, level $1 s, d$ 5, namely: no potential, less potential, do not know, have potential, and very potential, and questions with know or don't know answers. . The target respondents are students, teachers, and education personnel. As a result, an understanding of the geological disaster in Indramayu, namely the Earthquake with the average answer is level-3 (don't know), Tsunami level-3, and level-2 Volcanic Eruption, even though these disasters should not have the potential to occur (level-1), this is due to lack of knowledge about Geological disasters. Meanwhile, the lack of other knowledge is quite high, namely not knowing the potential for other natural disasters as much as 92\%, not knowing about $51 \%$ of the natural gas bursts in Indramayu, not knowing BNPB, PVMBG, and BMKG as much as 57\%, and not knowing BNPB pocket book as much as $68 \%$. In conclusion, the lack of knowledge about geological disasters is still above 50\%, therefore, it is necessary to do counseling on geological disasters for the general public to assist the tasks of BNPB or BPBD.

Keyword : Geological Disaster, Indramayu

\begin{abstract}
Abstrak
Bencana geologi di Palu-Donggala (Sulawesi Tengah), September 2018, menimbulkan bayak kerusakan korban jiwa. Pertengahan tahun 2018, terjadi semburan gas alam yang menimbulkan semburan api dan air panas di selatan Indramayu, diperkirakan adanya patahan/sesar aktif yang memotong batuan reservoir migas hingga permukaan bumi. Antisipasi bencana geologi tersebut bukan hanya tugas instansi milik pemerintah terkait, namun semua pihak terkait, seperti
\end{abstract}




\begin{abstract}
Akamigas Balongan. Tujuan penelitian ini adalah untuk mengukur seberapa tahu dan sigap dalam menghadapi bencana geologi, serta mengukur pengetahuan mengenai badan/instansi pemerintah yang menangani bencana geologi. SMK Migas Balongan, adalah SMK paling terkait dengan geologi khususnya migas. Penelitian dilakukan di bulan Desember 2018, dengan metode kuisioner dengan bobot pertanyaan potensi jenis bencana gelogi, level $1 \mathrm{~s}, \mathrm{~d} 5$, yaitu: tidak berpotensi, kurang berpotensi, tidak tahu, berpotensi, dan sangat berpotensi, dan pertanyaan dengan jawaban tahu atau tidak tahu. Sasaran responden adalah siswa, guru, dan tenaga pendidikan. Hasilnya, pemahaman mengenai bencana geologi di Indramayu yaitu Gempa Bumi dengan jawaban rata-rata adalah level-3 (tidak tahu), Tsunami level-3, dan Erupsi Gunungapi level-2, padahal bencana tersebut seharusnya tidak berpotensi terjadi (level-1), hal ini disebabkan kurang tahunya pengetahuan mengenai bencana Geologi. Sedangkan kurangnya pengetahuan lainnya cukup tinggi, yaitu tidak tahu potensi bencana alam lainnya sebanyak 92\%, tidak tahu semburan gas alam di Indramayu sebanyak 51\%, tidak tahu BNPB, PVMBG, dan BMKG sebanyak 57\%, dan tidak tahu buku saku BNPB sebanyak $68 \%$. Sebagai kesimpulan, kurangnya pengetahuan mengenai bencana geologi masih diatas $50 \%$, karena itu, perlu dilakukan penyuluhan mengenai bencana geologi untuk masyarakat umum untuk membantu tugas BNPB atau BPBD.
\end{abstract}

Kata Kunci: Bencana Geologi, Indramayu.

\title{
Pendahuluan
}

Negara Indonesia pertemuan antara 3 lempeng tektonik besar yaitu: lempeng Hindia-Australia, lempeng Eurasia, dan lempeng Pasifik, sehingga menjadi area yang sebagian besarnya berstatus rawan bencana geologi, seperti gempa bumi, tsunami, letusan gunungapi, dan lain-lain. hanya pulau Kalimantan bagian barat, tengah, dan selatan yang merupakan daerah aman di Indonesia.

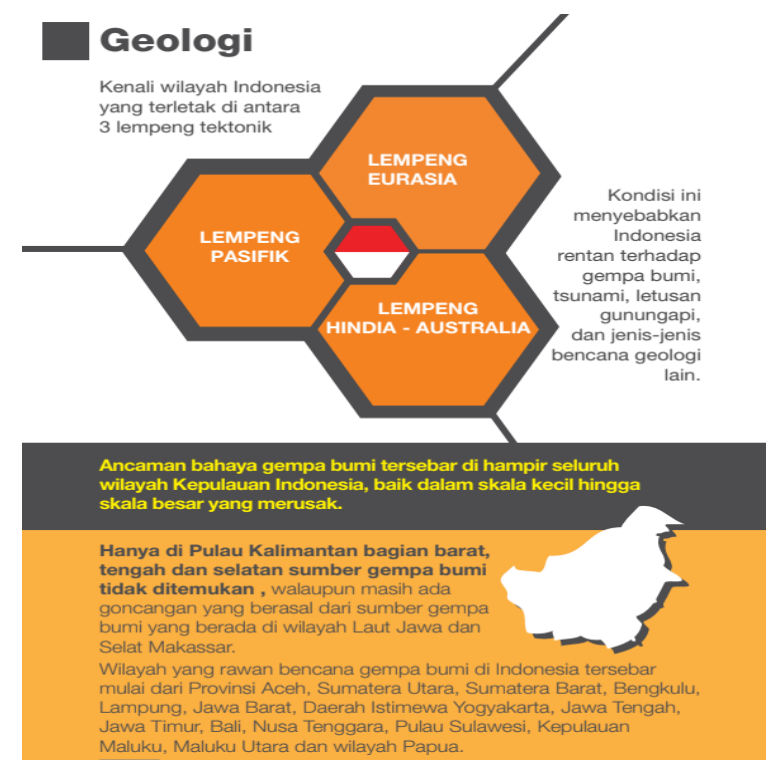

Gambar 1

Gambaran Indonesia sebagai area pertemuan 3 lempeng tektonik sehingga menyebabkan rawan bencana geologi (BNPB, 2017) . 
Bencana geologi di Palu-Donggala (Sulawesi Tengah), yang terjadi pada akhir September 2018, menimbulkan kerusakan besar hingga banyaknya korban jiwa. Berdasarkan Press Release BMKG NO: UM.505/9/D3/IX/2018, ditandatangani Deputi Bidang Geofisika, (Sadly, 2018), berdasarkan hasil monitoring BMKG hingga Pukul 02.55 WIB pada tanggal 28 September 2018, sudah terjadi 76 Gempabumi susulan yang terekam, dengan magnitudo terkecil M2.9 sedangkan terbesar M6,3.

Pada dasarnya bencana geologi tersebut dapat diminimalisir kerusakan dan kerugiannya apabila sudah dilakukan mitigasi secara menyeluruh, mulai dari sisi masyarakatnya hingga tiap pemerintah daerahnya, sehingga bukan hanya tugas untuk instansi pemerintahan yang berkaitan dengan bencana geologi saja seperti PVMBG (Pusat Vulkanologi dan Mitigasi Bencana Geologi), BMKG (Badan Meteorologi dan Klimatologi Geofisika), PSG (Pusat Survei Geologi), dan lain-lain saja namun tugas semua pihak termasuk civitas akademika di perguruan tinggi di Indonesia.

(Undang - Undang Nomor 24 Tahun 2007,) tentang Penanggulangan Bencana, halaman 6, disebutkan pemerintah pusat dan pemerintah daerah menjadi penanggung jawab penyelenggaraan penanggulangan bencana.

Dalam buku saku BNPB (BNPB, 2017), Badan Nasional Penanggulangan Bencana (BNPB) menjadi penanggung jawab penyelenggaraan penanggulangan bencana di tingkat nasional dengan didukung kementerian/Lembaga terkait, seperti Kementerian Pekerjaan Umum dan Perumahan Rakyat, Kementerian Kesehatan, Kementerian Sosial, Kementerian Dalam Negeri, TNI, Polri, Badan Pencarian dan Pertolongan (Basarnas), Badan Meteorologi, Klimatologi dan Geofsika (BMKG), Pusat Vulkanologi dan Mitigasi Bencana Geologi (PVMBG), dan kementerian/lembaga terkait lain.

Banyak upaya kesiapsiagaan bermanfaat dalam berbagai situasi bencana. Beberapa upaya penting untuk kesiapsiagaan adalah (BNPB, 2017),

1) Memahami bahaya di sekitar Anda.

2) Memahami sistem peringatan dini setempat. Mengetahui rute evakuasi dan rencana pengungsian.

3) Memiliki keterampilan untuk mengevaluasi situasi secara cepat dan mengambil inisiatif tindakan untuk melindungi diri.

4) Memiliki rencana antisipasi bencana untuk keluarga dan mempraktekkan rencana tersebut dengan latihan.

5) Mengurangi dampak bahaya melalui latihan mitigasi.

6) Melibatkan diri dengan berpartisipasi dalam pelatihan.

Secara umum, Indramayu kurang/minim berpotensi terjadi bencana alam, dibanding daerah lain di Indonesia. Potensi bencana akibat gunungapi terdekat yaitu Ciremai (kab. Kuningan). Berdasarkan (Utami, 2019). erupsi gunung Ciremai memiliki selang waktu istirahat terpendek 3 tahun dan terpanjang 112 tahun, mulai terekam sejak 1698 dan terakhir kali terjadi tahun 1937 (ESDM, 2014). Dengan demikian, jika saat ini tahun, maka letusan selanjutnya di perkirakan maksimal tahun 2039, atau 19 tahun lagi.

Potensi bencana gempa di Indramayu, seperti diberitakan (Republika, 2018), potensi gempa disebabkan adanya patahan Baribis, Cimanuk, dan Bumi Ayu. Patahan tersebut tercatat pernah bergerak pada 1990 sehingga menimbulkan gempa di daerah Talaga, Majalengka. Indramayu (belum pernah terjadi gempa besar) karena lebih jauh dari sumber-nya. sumbernya lebih cenderung ke selatan. Tapi tidak tertutup kemungkinan suatu waktu terjadi di bawah endapan kuarter. 


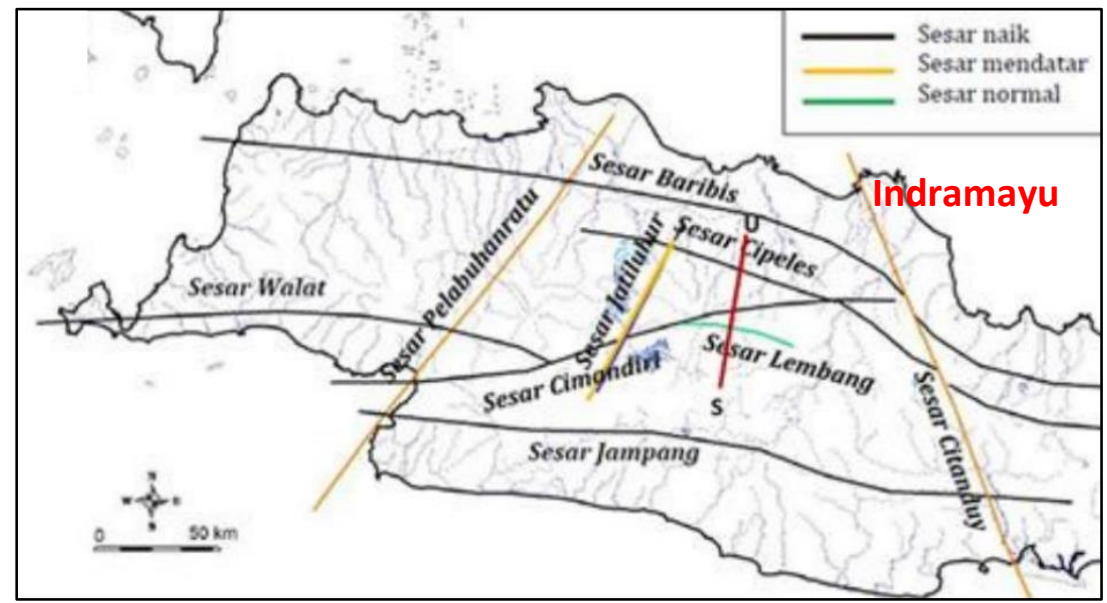

Gambar 2

Sesar Baribis di utara jawa barat menjangkau Indramayu memiliki tren barat-timur (Febyani et al., 2020)

Beberapa bulan lalu di kecamatan Tukdana (selatan Indramayu) terjadi semburan gas alam yang menimbulkan semburan api dan air panas, hal ini kemungkinan dua hal yaitu: disebabkan patahan yang dijelaskan sebelumnya, dan Indramayu yang merupakan lapangan minyak dan gas. Seperti yang diberitakan (detik, 2018), Kepala Subbidang Pemetaan Tematik PSG BG KESDM Isnu Hajar Sulistiyawan mengatakan dua desa berada di Kecamatan Tukdana yang diteliti merupakan wilayah relatif rawan bencana sekaligus lokasi semburan gas.
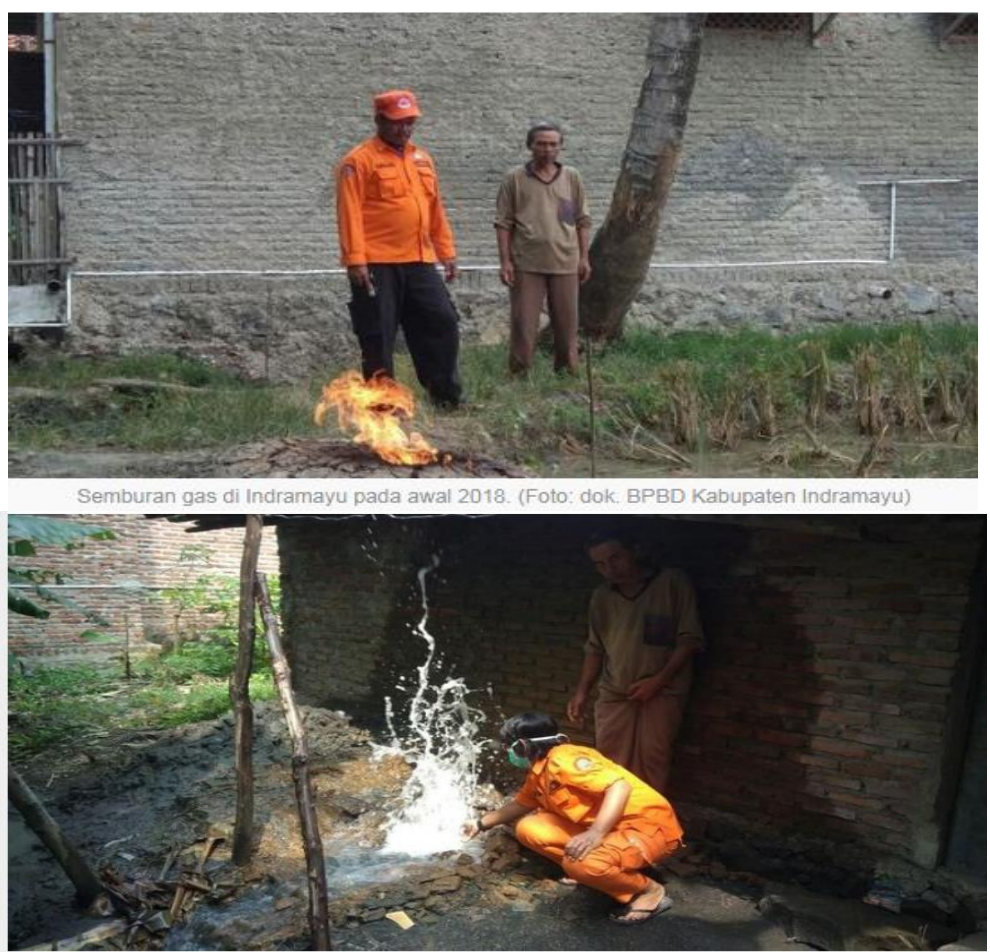

Gambar 3

Semburan gas alam di kecamatan Tukdana (detik, 2018). 
Dalam website (Kemendikbud, 2020), SMK Migas Balongan, merupakan suatu SMK berlokasi disekitar pusat pemerintahan Kab. Indrmamyu berdiri sejak 2016. Menurut kepala sekolahnya, SMK ini terdiri dari 3 jurusan, yaitu Teknik Pengeboran, Teknik Produksi Perminyakan, dan Teknik Kimia Industri, yang mana didalamnya terdapat mata pelajaran geologi dasar. Selain itu, siswa - siswinya sebagian berasal dari wilayah 3 Cirebon, yaitu Kab. Indramayu, Kab. Cirebon, dan Kota Cirebon. Pemahaman dan kesiapsiagaan terhadap bancana geologi khususnya di area Indramayu ini akan lebih efektif jika diawali dengan pengukuran tingkat pengetahuannya terlebih dahulu pada jenjang SMA (Sekolah Menengah Atas), termasuk SMK, untuk mengukur seberapa tahu dan sigap dalam menghadapi bencana geologi, serta mengukur pengetahuan mengenai badan/instansi pemerintah yang menangani bencana geologi, sehingga nantinya akan diketahui seberapa siap dan sigap civitas SMK dalam menghadapi potensi bencana tersebut.

\section{Metodologi Penelitian}

Metode penelitian Metode yang digunakan yaitu penyuluhan dan pengisian angket atau kuisioner dan studi pustaka dari internet (https://www.kelaspintar.id/, 2020). Jenis pertanyaan bersifat terbuka dan tertutup (Rojabi, 2019). Pertanyaan nomor 1 (satu) sampai dengan nomor terakhir, yaitu 6 (enam), mencakup pertanyaan tertutup karena membatasi responden pada jawaban-jawaban pilihan, kecuali pada nomor 3 (tiga), terdapat pertanyaan tambahan yang bersifat terbuka.

Penelitian ini terdiri dari dua tahap kegitan, yaitu Pengukuran pemahaman dan kesiapsiagaan yang dilakukan dengan penyebaran kuisioner / angket, terhadap civitas SMK Migas Balongan yang meliputi, siswa, guru, dan staf tenaga pendidikan hari Rabu, tanggal 5 Desember 2018, tahap yang kedua adalah menyampaikan hasil kuisioner kepada kepala SMK Migas Balongan.

Tabel 1

Contoh Kuisioner penilitian

\begin{tabular}{|c|l|c|c|c|c|c|}
\hline No & Pertanyaan & \multicolumn{3}{|l|}{ Lingkarilah Jawaban yang anda pilih } \\
\hline $\mathbf{1}$ & $\begin{array}{l}\text { Bagaimanakah potensi } \\
\text { bencana alam di } \\
\text { Indramayu }\end{array}$ & $\begin{array}{l}\text { Tidak } \\
\text { Ber- } \\
\text { potensi }\end{array}$ & $\begin{array}{l}\text { Kurang } \\
\text { Ber- } \\
\text { potensi }\end{array}$ & $\begin{array}{l}\text { Tidak } \\
\text { Tahu }\end{array}$ & $\begin{array}{l}\text { Cukup } \\
\text { Ber- } \\
\text { potensi }\end{array}$ & $\begin{array}{l}\text { Sangat } \\
\text { Ber- } \\
\text { potensi }\end{array}$ \\
\cline { 2 - 7 } & Gempa Bumi & 1 & 2 & 3 & 4 & 5 \\
\hline & Tsunami & 1 & 2 & 3 & 4 & 5 \\
\cline { 2 - 7 } & Erupsi Gunungapi & $\begin{array}{l}\text { Bagaimanakah potensi } \\
\text { bencana alam di sekitar } \\
\text { tempat tinggal / rumah } \\
\text { anda? }\end{array}$ & 1 & 3 & 4 & 5 \\
\hline $\mathbf{3}$ & $\begin{array}{l}\text { Apakah ada bencana } \\
\text { alam lain, selain } \\
\text { disebutkan diatas yang } \\
\text { terjadi di sekitar tempat } \\
\text { tinggal anda? }\end{array}$ & tidak ada & ada & Jika ada, tuliskan di kolom ini... \\
\hline $\mathbf{4}$ & $\begin{array}{l}\text { apakah anda } \\
\text { mengetahui terjadi } \\
\text { semburan gas alam di }\end{array}$ & tidak tahu & tahu & \multicolumn{4}{|l}{} \\
\hline
\end{tabular}




\begin{tabular}{|c|l|l|l|} 
& kec. Tukdana ? & & \\
\hline $\mathbf{5}$ & $\begin{array}{l}\text { apakah anda tahu } \\
\text { mengenai BNPB, } \\
\text { PVMBG, dan BMKG ? }\end{array}$ & tidak tahu & tahu \\
\hline $\mathbf{6}$ & $\begin{array}{l}\text { apakah anda tahu cara } \\
\text { mengetahui bencana } \\
\text { alam sesuai petunjuk } \\
\text { buku saku BNPB ? }\end{array}$ & tidak tahu & tahu \\
\hline
\end{tabular}

\section{Hasil Penelitian}

Berdasarkan hasil sebaran angket, pada hari Rabu 5 Desember 2018 di SMK Migas Balongan, didapatkan 37 sampel yang telah didapat, yang terdiri dari 6 guru, dan 31 siswa.

Hasil olahan angket / kuisioner tersebut disajikan dalam Tabel 2. Berdasarkan hasil olahan data angket tersebut, untuk pertanyaan nomor-1 di ketahui terdapat rata-rata jawaban tertinggi adalah level 4 yaitu; cukup berpotensi. di Indramayu adalah banjir, hal ini disebabkan beberapa kali Indramayu terkena banjir besar hasil limpasan/luapan sungai Cimanuk, tahun 2014 yang melanda sebagian kecamatan Indrmayu.

Tabel 2

Hasil Rekapitulasi Kuisioner Penilitian

\begin{tabular}{|c|c|c|c|}
\hline \multicolumn{4}{|c|}{ Rekap Jawaban Pertanyaan no 1 dan 2} \\
\hline 1 & $\begin{array}{l}\text { Bagaimanakah potensi bencana alam } \\
\text { di Indramayu }\end{array}$ & $\begin{array}{l}\text { Rerata Jawaban } \\
\text { responden }\end{array}$ & $\begin{array}{l}\text { Rerata level } \\
\text { Poin }\end{array}$ \\
\hline & Gempa Bumi & Tidak Tahu & 3 \\
\hline & Tsunami & Tidak Tahu & 3 \\
\hline & Erupsi Gunungapi & Kurang Berpotensi & 2 \\
\hline 2 & $\begin{array}{l}\text { Bagaimanakah potensi bencana alam di } \\
\text { sekitar tempat tinggal / rumah anda? }\end{array}$ & Kurang Berpotensi & 2 \\
\hline \multicolumn{4}{|c|}{ Prosentasi jawaban 3 s.d 6} \\
\hline 3 & $\begin{array}{l}\text { Apakah ada bencana alam lain, selain } \\
\text { disebutkan diatas yang terjadi di sekitar } \\
\text { tempat tinggal anda? }\end{array}$ & tidak ada $=92 \%$ & ada $=8 \%$ \\
\hline 4 & $\begin{array}{l}\text { apakah anda mengetahui terjadi } \\
\text { semburan gas alam di kec. Tukdana? }\end{array}$ & tidak tahu $=51 \%$ & $\operatorname{tahu}=49 \%$ \\
\hline 5 & $\begin{array}{l}\text { apakah anda tahu mengenai BNPB, } \\
\text { PVMBG, dan BMKG? }\end{array}$ & tidak tahu $=57 \%$ & $\operatorname{tahu}=43 \%$ \\
\hline 6 & $\begin{array}{l}\text { apakah anda tahu cara mengetahui } \\
\text { bencana alam sesuai petunjuk buku saku } \\
\text { BNPB ? }\end{array}$ & tidak tahu $=68 \%$ & $\operatorname{tahu}=32 \%$ \\
\hline
\end{tabular}




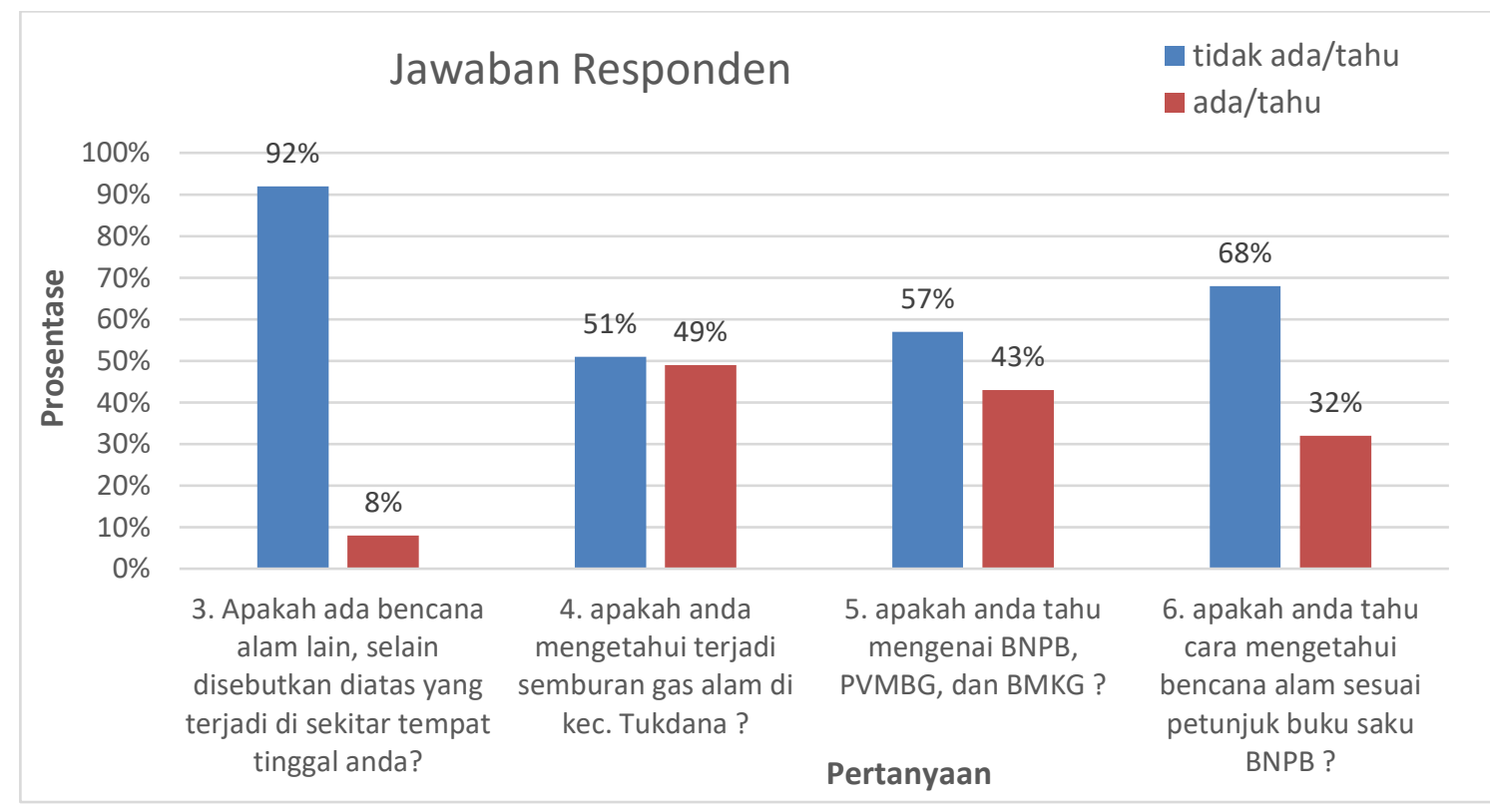

Gambar 4

Grafik Hasil Rekapitulasi Kuisioner Penilitian nomor 3 s.d 6

Untuk pertanyaan nomor-1 lainnya, ada tiga rata-rata jawaban level 3, yaitu gempa bumi, tsunami. Munculnya jawaban gempa bumi dan tsunami karena dekatnya Indramayu dengan area pantai utara, hal ini disebabkan ketidaktahuan responden mengenai keilmuan geologi, yang mana seharusnya tsunami hanya sangat mungkin terjadi di sepanjang sekitar zona subduksi (selatan pulau Jawa), yang mana hampir pasti tidak terjadi di pantura Indramayu.

Untuk pertanyaan ke-2, rata-rata responden menjawab potensi bencana alam di sekitar tempat tinggal responden menjawab kurang berpotensi. Untuk jawaban pertanyaan nomor 3, sebanyak $92 \%$ responden menjawab tidak ada potensi bencana selain dijelaskan sebelumnya, yang berarti, tempat tinggal para responden hampir semuanya berlokasi yang jauh dari bencana alam yang sudah disebutkan sebelumnya. Jawaban responden untuk pertanyaan nomor 4 yang menjawab hanya $49 \%$ yang tahu mengenai semburan api / gas alam di kec. Tukdana, yang berarti bahwa bencana tersebut banyak responden di area sekitar SMK Migas Balongan yang mendengar / mengetahui bencana alam tersebut.

Mengenai jawaban responden mengenai instansi yang berkaitan dengan bencana alam yaitu; BNPB, PVMBG, dan BMKG, ternyata banyak yang tidak tahu, dengan presentasi $57 \%$. untuk pertanyaan nomor 6 , mengenai buku saku BNPB, wajar apabila sejalan dengan dengan pertanyaan sebelumnya (nomor 5), yang tidak mengetahui buku pedoman tersebut dengan jumlah $68 \%$ dari total responden

\section{Kesimpulan}

Berikut adalah kesimpulan dari kegiatan pengabdian kepada masyarakat ini, diantaranya:

Pemahaman mengenai bencana geologi di Indramayu yaitu Gempa Bumi dengan jawaban rata-rata adalah level-3 (tidak tahu), Tsunami level-3, dan Erupsi Gunungapi level-2, padahal bencana tersebut seharusnya tidak berpotensi terjadi (level-1), karena Indramayu terletak di pantai utara jauh dari zona subdukdi, hal ini disebabkan kurang 
tahunya pengetahuan mengenai bencana Geologi, yang mana berdasar pengalaman yang terjadi sekitar dan informasi dari media.

Kurangnya pengetahuan lainnya cukup tinggi, yaitu tidak tahu potensi bencana alam lainnya sebanyak 92\%, tidak tahu semburan gas alam di Indramayu sebanyak $51 \%$, tidak tahu BNPB, PVMBG, dan BMKG sebanyak 57\%, dan tidak tahu buku saku BNPB sebanyak $68 \%$. Karena itu, perlu dilakukan penyuluhan mengenai bencana Geologi untuk masyarakat umum. 
Pengukuran Pemahaman dan Kesiapsiagaan Terhadap Potensi Bencana Geologi Area

Indramayu di SMK Migas Balongan

\section{BIBLIOGRAFI}

BNPB. (2017). Buku Saku - Tanggap Tangkas Tangguh Menghadapi Bencana.

detik. (2018). 150 Titik Semburan Gas Muncul di Indramayu. Retrieved from https://news.detik.com/berita-jawa-barat/d-4174615/150-titik-semburan-gasmuncul-di-indramayu

ESDM, Badan Geologi. (2014). Gunung Ciremai - Sejarah Letusan. Retrieved from https://vsi.esdm.go.id/index.php/gunungapi/data-dasar-gunungapi/527-gciremai?start $=1$

Febyani, Siska, Rivaldy, Mohammad, Syafri, Ildrem, Nur, Andi Agus, Embara, Patra, \& Nugroho, Sigit Dwi. (2020). Analisis Kerentanan Gempa pada Jalur Sesar Baribis menggunakan Metode Microearthquake (MEQ). Bulletin of Scientific Contribution: GEOLOGY, 18(1), 1-12.

https://www.kelaspintar.id/. (2020). https://www.kelaspintar.id/,.

Kemendikbud. (2020). Data Pokok Pendidikan. Direktorat Jenderal Pendidikan Anak Usia Dini, Pendidikan Dasar dan Pendidikan Menengah.

Republika. (2018). Badan Geologi Teliti Potensi Bencana di Indramayu. Retrieved from https://www.republika.co.id/berita/nasional/daerah/18/08/20/pdrqsf384-badangeologi-teliti-potensi-bencana-di-indramayu

Rojabi, Ahmad Ridho. (2019). Blended Learning via Schoology as a Learning Management System in Reading Class: Benefits and Challenges. Jurnal Linguistik Terapan, 9(2), 36-42.

Sadly, Muhammad. (2018). (2018). No Title.

Undang - Undang Nomor 24 Tahun 2007. (2007). Undang - Undang Nomor 24 Tahun 2007.

Utami, Dyah Nursita. (2019). KAJIAN DAMPAK PERUBAHAN IKLIM TERHADAP DEGRADASI TANAH. Jurnal Alami: Jurnal Teknologi Reduksi Risiko Bencana, $3(2), 122-131$. 